\title{
緊張係留構造物 (TLP)の不規則波中非線形応答
}

\author{
— 2 次を含めた高次の波力特性—— \\ 正員 加 藤 俊 司* Bin Teng** \\ 正員 斉 藤 昌 勝* \\ Nonlinear Response of a Tension Leg Platform \\ Characteristics of Second-order Sum Frequency Force and Higher Order Force -
}

by Shini Kato, Member Bin Teng,
Masakatsu Saito, Member

\section{Summary}

Recent tension leg platform (TLP) model tests have revealed strong transient resonant responses during extreme wave frequency responses. It is said that these responses, termed ringing, are associated with large-crested, near breaking wave events. In this paper, as a first step of giving light on the occurrence mechanism of such nonlinear phenomenon, first-order, second-order sum frequency and higher order wave force measurement tests are carried out in regular and irregular waves. At the same time, wave height distributions of the wave field inside the TLP are also measured to investigate the correlation between the occurrence condition of higher-order wave force and the wave height deformation. The first and second order wave force measurement tests are used to validate the predictions based on a newly developed first-order and second-order diffraction theory for an arbitrary three dimensional floating bodies. As a result, not only first-order wave forces but also second order sum frequency forces can be predicted from the second-order diffraction theory except for high frequency range $(k L>6, k$ : wave number, $L:$ distance between columns of TLP). However, a significant thirdorder surge force occurs when $k L$ becomes larger than 4.4 and has the same characteristics as the firstorder force. Furthermore, nonlinear force higher than second order occurs even in irregular waves when a crest pairing of waves occurs inside TLP. Such forces seem to be caused by what the surface elevation inside TLP become more steep and nonlinear, as compared with the incident wave, by a hydrodynamic nonlinear interaction between columns.

\section{1. はじめに}

緊張係留構造物 (TLP) は, テンドンと呼ばれる鋼管で 海底から緊張状態で係留された構造物である。現在までに 4 基(1984 年 Hutton(北海), 1990 年 Jolliet (メキシコ湾), 1992 年 Snorre (北海), 1994 年 Auger $(800 \mathrm{~m}$ 水深; メキ シコ湾))の TLP が稼働している。また, Heidrun TLP(こ れはコンクリート製のハルを有し 17 万トンと世界最大の TLP）が現在建造中である。

* 運輸省船舶技術研究所

** 中国大連工科大学

原稿受理 平成 7 年 7 月 10 日

秋季講演会において講演 平成 7 年 11 月 16,17 日
TLP の魅力はなんと言っても, 上下動が他の浮体構造物 に比べて小さい事である。これは，フレキシブルライザー に比べ低コストのリジッドライザーを使用でき，海底の装 置も簡素化できる点でセミサブ型の石油生産プラットフォ 一ムょりも優れている。また, 水深が深くなっても固定構 造物のように鋼材重量が增えるといった欠点も無くかつテ ンドンの重量を浮力とバランスさせることができるため将 来の石油生産プラットフォームの主流になると言われてい る。また, 近年, 沖合いの浮体式海上空港の半固定係留技 術としても緊張係留技術は注目されている。しかし一方で, その特殊な係留方式ゆえに, 弛緩係留構造物では特に問題 とならなかったような現象が設計及び構造物の安全性を左 右する重要な要因になる可能性がある。スプリンギング及 びリンギング応答は，まさにそれである。スプリンギング (Springing) 現象とは, 波と浮体との 2 次オーダーの非線 
形干涉によって生じる 2 次波力の和の周波数成分力によっ て引き起こされる上下方向の倍調波振動現象である。この 高周波振動は, テンドンの疲労損稘の大きな原因となるこ とから，その応答予測の研究は以前より実施されてお $\eta^{124)}$, 最近では, 2 次波力の和の周波数成分力を 2 次のポ テンシャル理論を用いて厳密に評価する手法が, 松井ら5), $\mathrm{Kim}^{6}$ によって開発され，実験結果との比較による理論の 妥当性の検証も行われている。しかしながら, 実験結果と の検証は, 問題となる周波数範囲 $(3<k L(=$ 波数 $\times$ 長さ) $<$ 15）に比べて低周波数域（ $0<k L<5.4 ）$ の規則波中でのみ 行われており，高周波数域での検証及び 2 次波力の和の周 波数成分力の伝達関数 (Quadratic Transfer Function：略 してQTFと称する）を含む不規則波中における実験結果 との検証はまだ行われていない。

スプリンギング応答に対してもまだ末解決の問題が残さ れているが，それにもましてより重要な問題が最近起こっ てきている。それはリンギング (Ringing) 現象である。こ の現象は, 10 年前に英国 Hutton TLP の流体力学プロジ エクトチームがひそかに命名したものである。あるストー 厶状態で Hutton TLP の模型実験を行っている最中に, ス プリンギング振動とは異なるバースト現象を伴う高次の振 動がテンドン張力に発生した。この振動の包絡波形が教会 のベルに似ているためにこの名がつけられたと言われてい る。この現象は，頻繁には発生せず，またテンドンに働く 最大張力に対してもそれほど有意ではないということで当 時は見過ごされたようである。その後 1990 年にノルウェー において Hutton TLPよりも大水深域でかつ排水量も大 きい Heidrun TLP の水槽模型試験が行われ，有意なりン ギング現象が観測された。しかしながら，原因はまだ不明 である。

当所では，このリンギング現象が本当に水槽においても 発生し，有意なものであるのかどうかを調查するため水槽 試験を行っている。使用した模型は Photo. 1 に示すような Snorre TLP (北海で現在稼働中) の 1/100 模型である。水 深は実機に相似にさせるために $3.1 \mathrm{~m} て ゙$ 行った。また，テ ンドンの軸剛性は実機 (模型スケールで $23 \mathrm{kgf} / \mathrm{cm}$ )のほほ

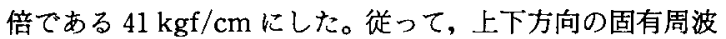
数を $5.8 \mathrm{~Hz}$ と波の周波数成分力をできるだけ受けない状 況下で実験を行った。実験は三鷹第三試験水槽（長さ 150 $\mathrm{m}$ ，幅 $7.5 \mathrm{~m}$ )において不規則波中のみで行った。Fig. 1 に 波スペクトル中心周波数 $0.8 \mathrm{~Hz}$ (実機で $12.5 \mathrm{sec}$ ), 有義波 高 $8.6 \mathrm{~cm}$ (実機て $8.6 \mathrm{~m}$ ) の時の波の時系列（波高計は浮 体前方 $6.75 \mathrm{~m}$ の位置にセットされているので浮体中央に 線形位相補正をほどこしてある）及び上下加速度，テンド ン張力の時系列を示す。またFig. 2 に波の周波数成分を cut した上下加速度とテンドン張力の時系列を示す。明ら かに，バースト現象を伴う異常振動が発生していることが わかる。この現象が発生している時刻を拡大すると Fig. 3

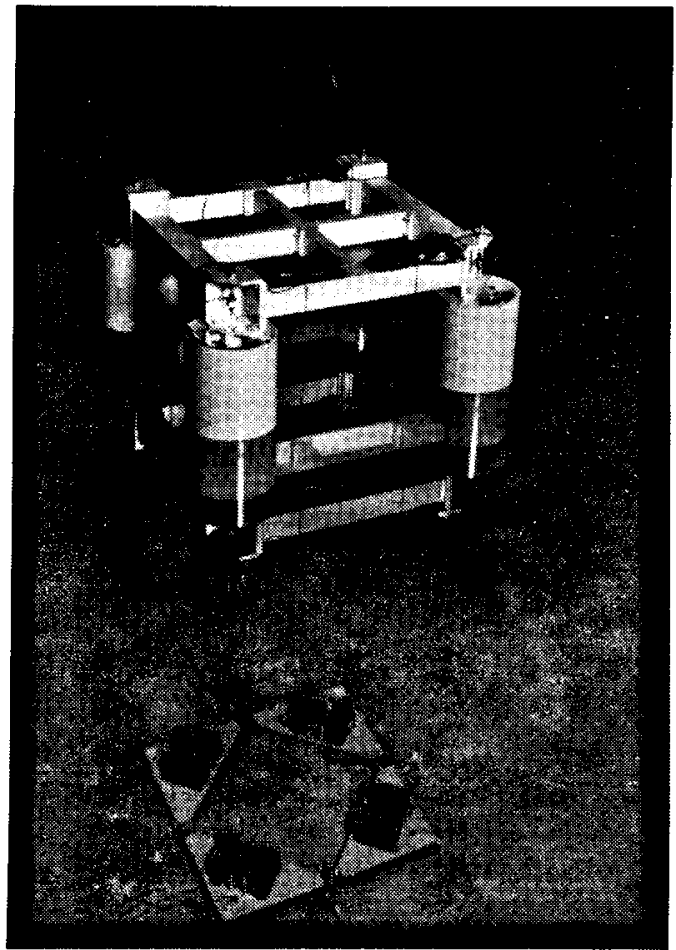

Photo 1 TLP model test set-up

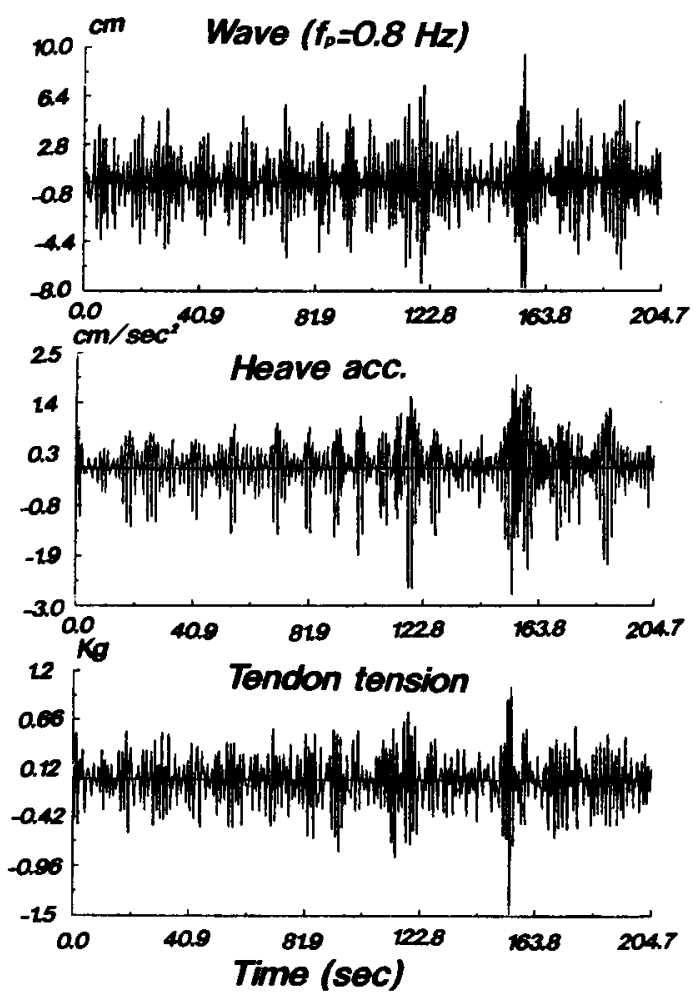

Fig. 1 An example of measured data of irregular wave, heave acceleration and tendon tension 
のようになり，大きな波の周波数のほほ倍の周波数成分を もつ振動（スプリンギング現象）が生じてから起こってい
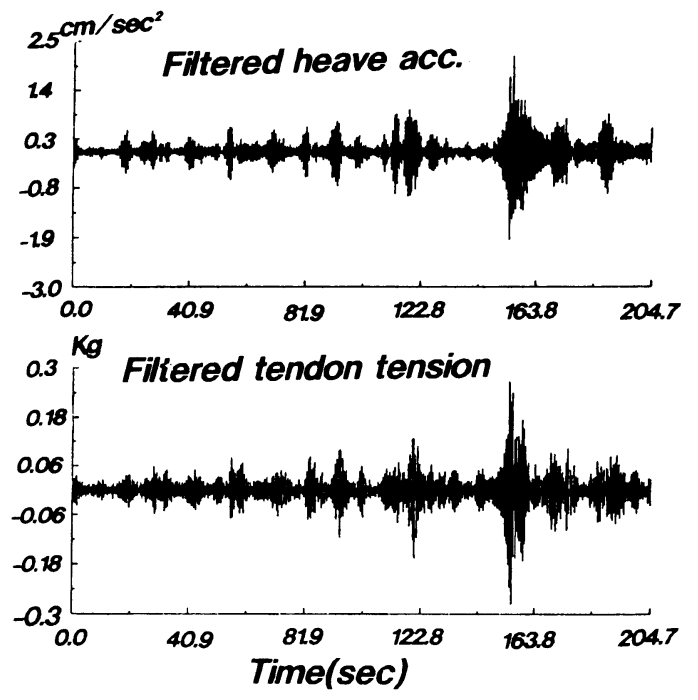

Fig. 2 Filtered time histories of heave acceleration and tendon tension
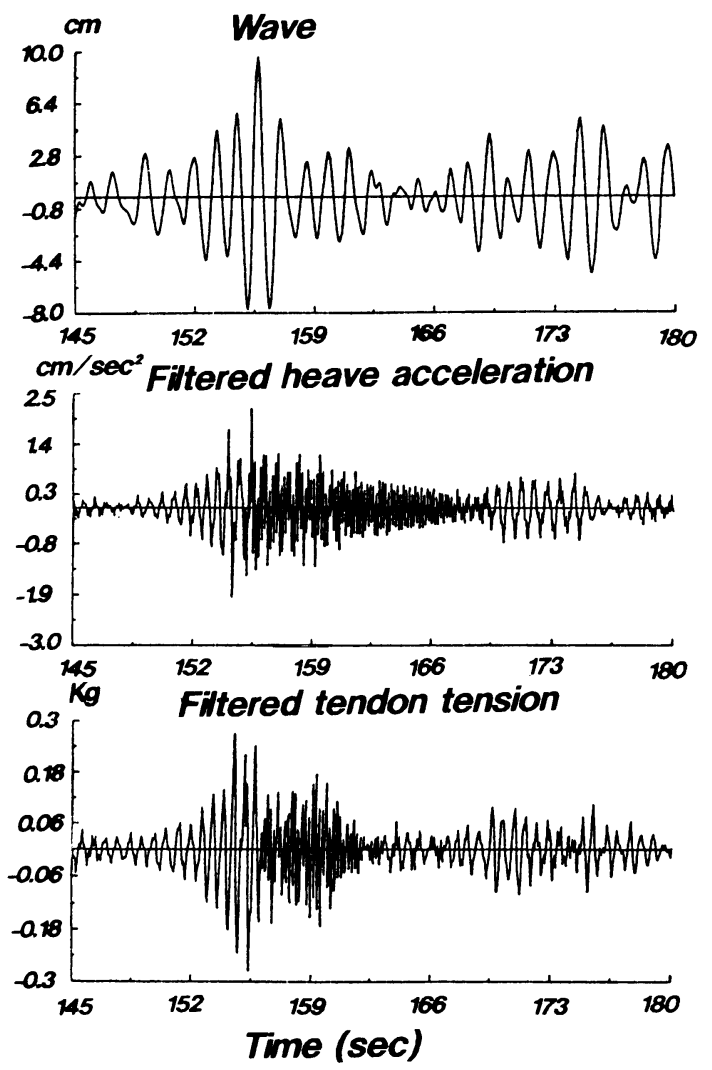

Fig. 3 Magnifying figures of horizontal axis in Fig. 2
ることがわかる。Fig. 4 はこのときのスペクトルを表して いる。たしかに, $6 \mathrm{~Hz}$ 付近の上下固有振動数付近に鋭い山 がある。また張力に対するもう一つの山は, Pitch の同調点 である。このように，水槽に扔いてリンギング現象らしき ものは発生することが確認されている。 Natvig? は, さら に Heidrun TLPの詳細な水槽試験からリンギング現象に 関し以下を指摘している。

・リンギングは波スペクトルの中心周期が 10 秒以上の とき発生する。

・砕波まではいたらない高 steep の波が入射したときに リンギングは良く起こる。

・全体的にリンギングの発生頻度は波高の 3 乗に比例 し，ピーク周期の 2 乗に反比例するようである。

・リンギングは 3 時間の間で 5 回程度しか発生しない。

・リンギングによるテンドン最大張力は非ガウス過程で あり，分布関数を推定することは現象がまれなためほ とんど不可能である。また，定常かどうかもわからな い。

・リンギングはすべての出会い角で発生し, 特に $45^{\circ}$ の

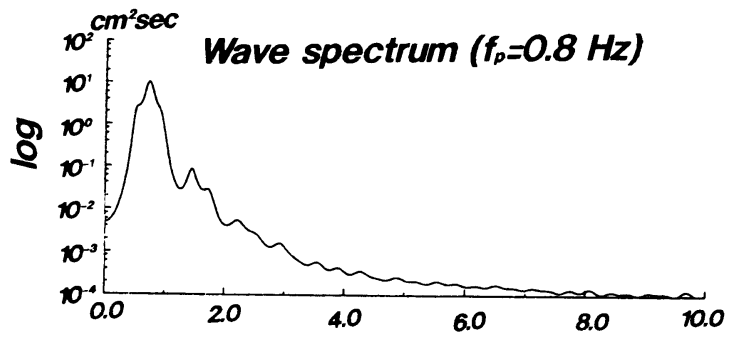
$\left(\mathrm{cm} / \mathrm{sec}^{2}\right)^{2} \mathrm{sec}$
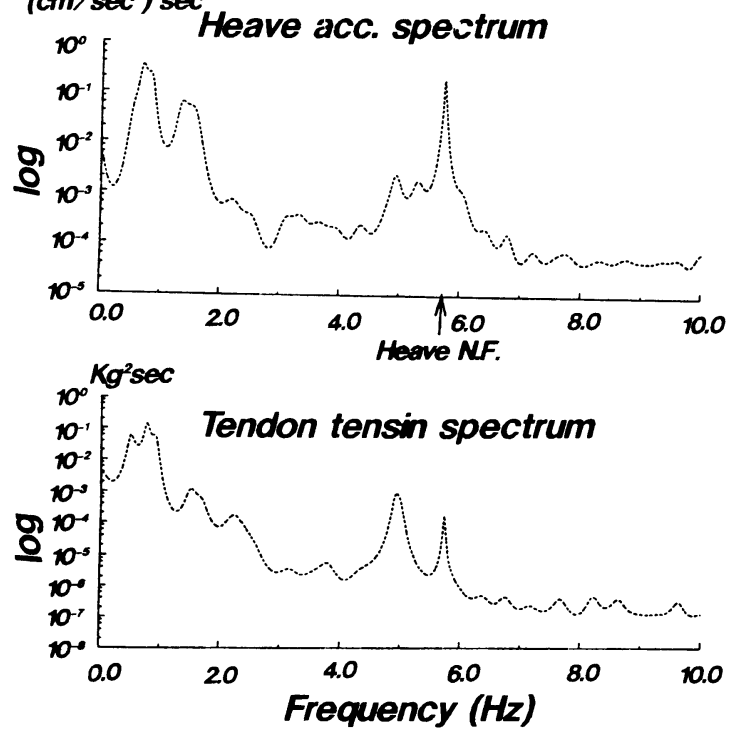

Fig. 4 Wave, heave acceleration and tendon tension spectra 
方向から波がくる場合は, 正面あるいは斜め波の場合 に比べて 2 倍以上の大きな Tether Ringing が発生す る。

・リンギング現象は重心の上下変化に敏感である。

・リンギングの最大值にはダンピングはあまり寄与しな い。

・リンギングを含む張力の極值分布はレイリー分布の裾 に比べて 3 から 4 倍広い。

本論の目的は, リンギング現象のメカニズムの解明及び その応答の最大值の確率予測にあるが, 今回はその第一報 として, リンギング現象解明の第一歩として 2 次を含めた 高次波力の評価について報告する。

\section{2 次波力の理論的評価}

流体は非回転の理想流体であり, 速度ポテンシャル $\Phi$ の 存在を仮定する。つまり, 流体の支配方程式は次の Laplace の方程式を満足する。

\section{$\Delta \Phi=0$}

ただし, 座標系として, 浮体中心と静止水面の交点を原点 とし, 鉛直上向きを $z$ 軸の正とする右手系とする。こうし た条件の下に 2 次波力の理論を考える。

\section{1 定式化}

まず，周波数 $\omega_{1}$ と $\omega_{2}$ の 2 つの入射波と浮体との干涉問 題を考える。波形勾配を微小パラメータとして速度ポテン シャルが次のような級数に展開できると仮定する。

$$
\Phi(x, t)=\epsilon \Phi^{(1)}(x, t)+\epsilon^{2} \Phi^{(2)}(x, t)+\cdots
$$

この時, 1 次の速度ポテンシャル $\Phi^{(1)}$ は各成分波ごとに考 えれば良いので

$$
\Phi^{(1)}(x, t)=\Re\left[\sum_{j=1}^{2} \phi_{j}^{(1)}(x) e^{-i \omega_{j} t}\right]
$$

と表される。また, 2 次の速度ポテンシャルは和周波数成 分, 差周波数成分の重ねあわせとなり, 次のように表す事 ができる。

$$
\Phi^{(2)}(x, t)=\Re\left[\sum_{j=1}^{2} \sum_{l=1}^{2}\left[\phi_{j l}^{-}(x) e^{-i \omega_{\overline{j l}}^{-} t}+\phi_{j l}^{+}(x) e^{-i \omega_{j l}^{+} t}\right]\right.
$$

$\omega_{j l}^{ \pm}=\omega_{j} \pm \omega_{l}$ である。

2 次のポテンシャル $\Phi^{(2)}$ を 2 次の入射波ポテンシャル $\Phi_{1}^{(2)}$, diffraction ポテンシャル $\Phi_{D}^{(2)}$, radiation ポテンシャ ル $\Phi_{R}^{(2)}$ を用いて次のように

$$
\Phi^{(2)}(x, t)=\Phi_{I}^{(2)}(x, t)+\Phi_{D}^{(2)}(x, t)+\Phi_{R}^{(2)}(x, t)
$$

分解すれば, radiation ポテンシャルが満たすべき境界条 件は

$[F]:-\omega_{j l}^{ \pm 2} \phi_{R j l}^{ \pm}+g \frac{\partial \phi_{R j l}^{ \pm}}{\partial z}=0 \quad$ on $z=0$

$[H]: \frac{\partial \phi_{R j l}^{ \pm}}{\partial n}=-i \omega_{j l}^{ \pm} \boldsymbol{n} \cdot\left(\xi_{j l}^{ \pm}+\alpha_{j l}^{ \pm} \times \boldsymbol{x}\right) \quad$ on $\quad S_{B}(x, y, z)$

$[B]: \frac{\partial \phi_{R j l}^{ \pm}}{\partial z}=0$ on bottom

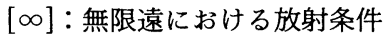

となる。ここで, $S_{B}$ は没水浮体表面, $\boldsymbol{\xi}$ と $\boldsymbol{\alpha}$ は, 浮体動摇 の変位と回転角ベクトルである。

同様に, diffraction ポテンシャルに対しては,

$[F]:-\omega_{j l}^{ \pm 2} \phi_{D j l}^{ \pm}+g \frac{\partial \phi_{D j l}^{ \pm}}{\partial z}=Q_{j l}^{ \pm}(x)$ on $z=0$

$[H]: \frac{\partial \phi_{D j l}^{ \pm}}{\partial n}=-\frac{\partial \phi_{I j l}^{ \pm}}{\partial n}+B_{j l}^{ \pm}(x) \quad$ on $\quad S_{B}(x, y, z)$

$[B]: \frac{\partial \phi_{D j l}^{ \pm}}{\partial z}=0$ on bottom

$[\infty]$ : out-going 条件

$Q_{j l}^{ \pm}$は和及び差の周波数成分を持つ自由表面上の強制圧力 分布を表し，それぞれ 1 次のポテンシャルから次のように 表される。

$$
Q_{j l}^{+}=\frac{1}{2}\left(q_{j l}^{+}+q_{l j}^{+}\right), \quad Q_{\overline{j l}}^{-}=\frac{1}{2}\left(q_{\overline{j l}}^{-}+q_{\overline{l j}}^{-*}\right)
$$

ただし

$$
\begin{aligned}
q_{j l}^{+}= & -\frac{i \omega_{l}}{2 g} \phi_{l}^{(1)}\left(-\omega_{j}^{2} \frac{\partial \phi_{j}^{(1)}}{\partial z}+g \frac{\partial^{2} \phi_{j}^{(1)}}{\partial z^{2}}\right) \\
& +i \omega_{l} D \phi_{j}^{(1)} \cdot \nabla \phi_{l}^{(1)}-q_{r r j l}^{+} \\
q_{\overline{j l}}^{-}= & \frac{i \omega_{l}}{2 g} \phi_{l}^{(1) *}\left(-\omega_{j}^{2} \frac{\partial \phi_{j}^{(1)}}{\partial z}+g \frac{\partial^{2} \phi_{j}^{(1)}}{\partial z^{2}}\right) \\
& -i \omega_{l} D \phi_{j}^{(1)} \cdot \nabla \phi_{l}^{(1) *}-q_{r r j l}^{-}
\end{aligned}
$$

ここで, $q_{r r}$ は, 入射波ポテンシャルが満たすべき自由表面 条件を表す。また，*は複素共役を意味する。

$B_{j l}^{ \pm}$は和及び差の周波数成分を持つ物体表面の強制速度 分布であり，次のように表される。

$$
B_{j l}^{+}=\frac{1}{2}\left(b_{j l}^{+}+b_{l j}^{+}\right), \quad B_{j l}^{-}=\frac{1}{2}\left(b_{\overline{j l}}^{-}+b_{l j}^{-*}\right)
$$

ただし，

$$
\begin{aligned}
b_{j l}^{+}= & \frac{1}{2}\left[\boldsymbol{n} \cdot\left(-i \omega_{l}\left[H_{j l}^{+}\right] \boldsymbol{r}\right)-\boldsymbol{n} \cdot\left(\chi_{j} \cdot \nabla\right) \nabla \phi_{l}^{(1)}\right. \\
& \left.+\left(\alpha_{j}^{(1)} \times \boldsymbol{n}\right) \cdot\left[-i \omega_{l} \chi_{l}-\nabla \phi_{l}^{(1)}\right]\right] \\
b_{j l}^{-}= & \frac{1}{2}\left[\boldsymbol{n} \cdot\left(i \omega_{l}\left[H_{j l}^{-}\right] \boldsymbol{r}\right)-\boldsymbol{n} \cdot\left(\chi_{j} \cdot \nabla\right) D \phi_{l}^{(1) *}\right. \\
& \left.+\left(\alpha_{j}^{(1)} \times \boldsymbol{n}\right) \cdot\left[i \omega_{l} \chi_{l}^{*}-\nabla \phi_{l}^{(1) *}\right]\right]
\end{aligned}
$$

また，

$$
\boldsymbol{x}=\boldsymbol{\xi}^{(1)}+\boldsymbol{\alpha}^{(1)} \times \boldsymbol{r}
$$

であり,

$$
\begin{aligned}
& H_{j l}^{+}=-\frac{1}{2} \\
& \times\left[\begin{array}{ccc}
\alpha_{y j}^{(1)} \alpha_{y l}^{(1)}+\alpha_{z j}^{(1)} \alpha_{z l}^{(1)} & 0 & 0 \\
-2 \alpha_{x j}^{(1)} \alpha_{y l}^{(1)} & \alpha_{r i}^{(1)} \alpha_{x l}^{(1)}+\alpha_{z j}^{(1)} \alpha_{z l}^{(1)} & 0 \\
-2 \alpha_{x j}^{(1)} \alpha_{z l}^{(1)} & -2 \alpha_{y j}^{(1)} \alpha_{z l}^{(1)} & \alpha_{x j}^{(1)} \alpha_{x l}^{(1)}+\alpha_{y j}^{(1)} \alpha_{y l}^{(1)}
\end{array}\right]
\end{aligned}
$$

$$
\begin{gathered}
H_{j l}^{-}=-\frac{1}{2} \\
\times\left[\begin{array}{ccc}
\alpha_{y j}^{(1)} \alpha_{y l}^{(1) *}+\alpha_{z j}^{(1)} \alpha_{z l}^{(1) *} & 0 & 0 \\
-2 \alpha_{x j}^{(1)} \alpha_{y l}^{(1) *} & \alpha_{x j}^{(1)} \alpha_{x l}^{(1) *}+\alpha_{z j}^{(1)} \alpha_{z l}^{(1) *} & 0 \\
-2 \alpha_{x j}^{(1)} \alpha_{z l}^{(1) *} & -2 \alpha_{y j}^{(1)} \alpha_{z l}^{(1) *} & \alpha_{x j}^{(1)} \alpha_{x l}^{(1) *}+\alpha_{y j}^{(1)} \alpha_{y l}^{(1) *}
\end{array}\right]
\end{gathered}
$$


2 次の radiation ポテンシャルを求める問題は, グリーン 関数のみが異なるだけで線形の radiation ポテンシャルを 求めることと等価である。それゆえ，2次の diffraction ポ テンシャルを求める方法についてのみ示す。

\section{2 稳分方程式と数优解法}

周波数 $\omega_{5 l}^{ \pm} て ゙$ 振動するソースのグリーン関数 $G^{ \pm}$と diffraction ポテンシャル $\phi_{D j \ell}^{+}$に対し,グリーンの定理を用 いると diffraction ポテンシャルに対し次の積分方程式を 得る。

$$
\begin{aligned}
& C\left(x_{0}\right) \phi_{D j l}^{ \pm}\left(x_{0}\right)-\int_{S_{F}} \frac{\partial G^{ \pm}\left(x, x_{0}\right)}{\partial n} \phi_{D j l}^{ \pm}(x) d S \\
& \quad=\int_{s_{B}} G^{ \pm}\left(x, x_{0}\right)\left[\frac{\partial \phi_{j l i}^{ \pm}(x)}{\partial n}-B_{j l}^{ \pm}(x)\right] d S \\
& \quad+\int_{S_{F}} G^{ \pm}\left(x, x_{0}\right) Q_{j l}^{ \pm}(x) d S
\end{aligned}
$$

ただし， $S_{F}$ は無限遠までの自由表面を表す。この式の solid angle $C$ と物体表面におけるグリーン関数の法線微分の特 異性は，次式で表される新たなグリーン関数

$$
G_{0}=-\left[\frac{1}{r}+\frac{1}{r_{1}}+\frac{1}{r_{2}}+\frac{1}{r_{3}}\right]
$$

を導入する事で回避することができる。ただし，

$$
\begin{aligned}
& r=\left[R^{2}+\left(z-z_{0}\right)^{2}\right]^{1 / 2} \\
& r_{1}=\left[R^{2}+\left(z+z_{0}\right)^{2}\right]^{1 / 2} \\
& r_{2}=\left[R^{2}+\left(z-z_{0}-2 h\right)^{2}\right]^{1 / 2} \\
& r_{3}=\left[R^{2}+\left(z+z_{0}+2 h\right)^{2}\right]^{1 / 2} \\
& R=\left[\left(x-x_{0}\right)^{2}+\left(y-y_{0}\right)^{2}\right]^{1 / 2}
\end{aligned}
$$

なお, $h$ は水深である。この新たなグリーン関数を用いる

と, 積分方程式 (14) は次のように変形される。

$$
\begin{aligned}
(1 & \left.+\int_{s_{1}} \frac{\partial G_{0}}{\partial n} d x d y\right) \phi_{D j l}^{ \pm}\left(x_{0}\right) \\
& -\int_{S_{F}}\left[\frac{\partial G^{ \pm}}{\partial n} \phi_{D j l}^{ \pm}(x)-\frac{\partial G_{0}}{\partial n} \phi_{D j l}^{ \pm}\left(x_{0}\right)\right] d S \\
& =\int_{s_{B}} G^{ \pm}\left(x, x_{0}\right)\left[\frac{\partial \phi_{I j l}^{ \pm}(x)}{\partial n}-B_{j l}^{ \pm}(x)\right] d S \\
& +\int_{S_{F}} G^{ \pm}\left(x, x_{0}\right) Q_{j l}^{ \pm}(\boldsymbol{x}) d S
\end{aligned}
$$

この式の物体表面における強制速度分布の積分には, 1 次 ポテンシャルの 2 階微分項を含んでいる。2 階微分の数值 計算は, 1 階の数值微分に比べて非常に精度が悪いのでこ
れを回避する必要がある。Teng and Eatock-Taylor ${ }^{8), 91}$ は 2 階微分を含む積分を 1 階の微分のみの数值積分で表す変 换を示しており，今回は彼らの方法を用いる。また，自由 表面の強制圧力分布 $Q$ は, 浮体からの距離に対しゅるやか にしか減衰しないので, 無限遠までの自由表面積分の数值 計算には十分注意が必要である。ここでは, 自由表面を Fig. 5 に示すように 3 つの領域に分割し, それぞれの領域 に対し異なる積分を実行する。第 1 の領域である $S_{F}$ では, 自由表面をメッシュ分割し, 数值積分で求める。ただし, この場合も 1 次ポテンシャルの 2 階微分項があるので, こ れを 1 階微分項のみの積分に変換して数値積分を行う。

第 2 の領域である $S_{F 2}$ 内では, グリーン関数及び 1 次ポ テンシャルを極座標を変数とするフーリエ級数の形で表現 する。フーリエモードの直交性を用いるとこの領域内の表 面積分は半径方向のみの線積分で表されるので, 容易に積 分は実行される。

evanescent モードを無視すれば第 3 の領域 $S_{F_{3}}$ では, Hankel 関数の 3 重積の積分で表される。この領域の積分 を次の 2 つの積分領域に分割する。

$$
\int_{R_{s}}^{\infty}=\int_{R_{s}}^{R_{s 1}}+\int_{R s 1}^{\infty}
$$

右辺第 1 項の積分には, 放密な Hankel 関数を用い, 第 2 項 の積分には Hankel 関数の漸近展開を用いる。両者の積分 の和が一定值に収束するまで $R_{s_{1}}$ を変化させることで積 分が実行できる。

\subsection{2 次の波力の QTF}

2 成分入射波中における 2 次の波力は次式で表される。

$$
\begin{aligned}
& \boldsymbol{F}^{(2)}=\Re\left[\sum _ { j = 1 } ^ { 2 } \sum _ { l = 1 } ^ { 2 } \left[A_{j} A_{l}^{*} \boldsymbol{f}_{j l}^{-}(\boldsymbol{x}) e^{-i \omega_{j l} t}\right.\right. \\
& \left.\left.+A_{j} A_{l} \boldsymbol{f}_{j l}^{+}(\boldsymbol{x}) e^{-i \omega_{\boldsymbol{H}^{t}} t}\right]\right]
\end{aligned}
$$

ここで, $A_{j}, A_{l}$ はそれぞれ周波数 $\omega_{j}, \omega_{l}$ の入射波複素振 幅， $f_{j l}^{ \pm}$は通常和及び差の周波数伝達関数（QTF と呼ばれ る）である。（16）式から和及び差の周波数をもつ2次の速 度ポテンシャルが求まれば，物体表面上での流体圧が求め られ，物体表面上でそれを積分すれば QTF が求められる。 QTF $f_{j l}^{ \pm}$は, 2 次のポテンシャルによる奇与 $f_{p j l}^{ \pm}$と 1 次の

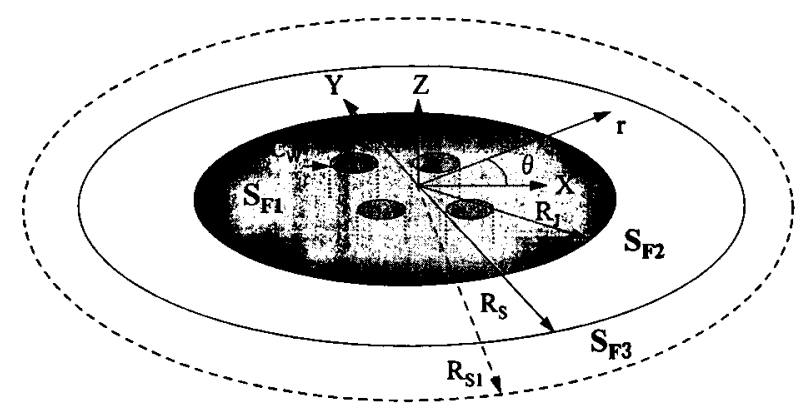

Fig. 5 Definition of free surface integral regions 
ポテンシャル及び応答による寄与 $\boldsymbol{f}_{q j l}^{ \pm}$に分割することがで きる。つまり

$$
\boldsymbol{f}_{j l}^{ \pm}=\boldsymbol{f}_{p_{j l}}^{+}+\boldsymbol{f}_{q j l}^{ \pm}
$$

に分割すれば，それぞれ次のように表される。

$$
\begin{aligned}
\boldsymbol{f}_{p j l}^{+} & =\frac{\rho}{2} \iint_{S_{B}} i \omega_{j l}^{ \pm}\left(\phi_{I j l}^{ \pm}+\phi_{D j l}^{ \pm}\right) \boldsymbol{n} d S \\
\boldsymbol{f}_{q j l}^{+} & =-\frac{\rho}{4} \iint_{S_{B}}\left[\nabla \phi_{j}^{(1)} \cdot \nabla \phi_{l}^{(1)}-i \omega_{j} \nabla \phi_{j}^{(1)} \cdot \chi_{l}^{(1)}\right. \\
& \left.-i \omega_{l} \nabla \phi_{l}^{(1)} \cdot \chi_{j}^{(1)}\right] \boldsymbol{n} d S+\frac{\rho g}{4} \oint_{C W} \zeta_{j}^{(1)} \zeta_{l}^{(1)} N d l \\
& +\frac{1}{2}\left(\alpha_{j}^{(1)} \times \boldsymbol{f}_{l}^{(1)}+\alpha_{l}^{(1)} \times \boldsymbol{f}_{j}^{(1)}\right) \\
& -\frac{1}{2} \rho g A w\left[\alpha_{3 j}^{(1)}\left(x_{f} \alpha_{1 l}^{(1)}+y_{f} \alpha_{2 l}^{(1)}\right)\right. \\
& \left.+\alpha_{3 l}^{(1)}\left(x_{f} \alpha_{1 j}^{(1)}+y_{f} \alpha_{2 j}^{(1)}\right)\right] \boldsymbol{k} \\
\boldsymbol{f}_{q j l}^{-} & =-\frac{\rho}{4} \iint_{S_{B}}\left[\nabla \phi_{j}^{(1)} \cdot \nabla \phi_{l}^{(1) *}-i \omega_{j} \nabla \phi_{j}^{(1)} \cdot \chi_{l}^{(1)}\right. \\
& \left.+i \omega_{l} \nabla \phi_{l}^{(1) *} \cdot \chi_{j}^{(1)}\right] \boldsymbol{n} d S+\frac{\rho g}{4} \oint_{C W^{\prime}} \zeta_{j}^{(1)} \zeta_{l}^{(1) *} \boldsymbol{N} d l \\
& +\frac{1}{2}\left(\alpha_{j}^{(1)} \times \boldsymbol{f}_{l}^{(1)}+\alpha_{l}^{(1) *} \times \boldsymbol{f}_{j}^{(1)}\right)
\end{aligned}
$$

Table 1 Comparison of sum frequency QTFs for a freely moving hemisphere in a water depth of $h / a=3$. The upper right triangular matrix is for the horizontal force, and the lower the vertical force. Computed values are for : first row, the quadratic term from the first order

\begin{tabular}{|c|c|c|c|c|c|}
\hline \multirow{2}{*}{$k_{l} a$} & $k_{2} a$ & 0.8 & 1.2 & 1.6 & 2.0 \\
\hline & Pres. Kim & Pres. Kim & Pres. Kim & Pres. Kim & Pres. Kim \\
\hline 0.8 & \begin{tabular}{|ll}
1.466 & 1.485 \\
1.566 & 1.641 \\
0.675 & 0.671 \\
0.174 & 0.131
\end{tabular} & $\begin{array}{ll}1.231 & 1.244 \\
0.729 & 0.681 \\
0.526 & 0.535 \\
0.514 & 0.541\end{array}$ & $\begin{array}{lll}1.709 & 1.697 \\
0.640 & 0.617 \\
1.059 & 0.992 \\
0.760 & 0.673\end{array}$ & $\begin{array}{lll}1.149 & 1.149 \\
0.357 & 0.326 \\
0.786 & 0.779 \\
0.420 & 0.407\end{array}$ & $\begin{array}{lll}1.040 & 1.040 \\
0.333 & 0.305 \\
0.652 & 0.649 \\
0.326 & 0.328\end{array}$ \\
\hline 1.2 & $\begin{array}{lll}1.906 & 1.885 \\
2.447 & 2.461 \\
0.663 & 0.648 \\
0.594 & 0.628\end{array}$ & $\begin{array}{ll}2.149 & 2.085 \\
3.266 & 3.219 \\
1.213 & 1.204 \\
2.332 & 2.338\end{array}$ & $\begin{array}{ll}2.902 & 2.871 \\
1.059 & 1.031 \\
2.370 & 2.336 \\
1.100 & 1.067\end{array}$ & $\begin{array}{lll}2.394 & 2.373 \\
0.747 & 0.727 \\
2.256 & 2.233 \\
0.903 & 0.879\end{array}$ & $\begin{array}{lll}2.169 & 2.151 \\
0.660 & 0.642 \\
2.072 & 2.060 \\
0.775 & 0.761\end{array}$ \\
\hline 1.6 & $\begin{array}{lll}0.723 & 0.712 \\
1.173 & 1.177 \\
0.176 & 0.169 \\
0.507 & 0.525\end{array}$ & $\begin{array}{lll}0.793 & 0.771 \\
1.455 & 1.483 \\
1.432 & 1.109 \\
2.087 & 1.632\end{array}$ & $\begin{array}{ll}0.383 & 0.378 \\
0.645 & 0.638 \\
1.332 & 1.331 \\
1.380 & 1.383\end{array}$ & $\begin{array}{lll}2.027 & 2.010 \\
0.472 & 0.458 \\
2.321 & 2.249 \\
0.833 & 0.778\end{array}$ & $\begin{array}{lll}1.840 & 1.823 \\
0.389 & 0.368 \\
2.139 & 2.079 \\
0.772 & 0.694\end{array}$ \\
\hline \multirow[t]{2}{*}{2.0} & $\begin{array}{lll}0.384 & 0.375 \\
0.761 & 0.763 \\
0.091 & 0.088 \\
0.467 & 0.479\end{array}$ & $\begin{array}{lll}0.441 & 0.431 \\
0.912 & 0.901 \\
0.999 & 0.994 \\
1.279 & 1.278\end{array}$ & 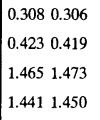 & $\begin{array}{lll}0.284 & 0.284 \\
0.290 & 0.288 \\
1.971 & 1.977 \\
1.912 & 1.918\end{array}$ & $\begin{array}{ll}1.681 & 1.665 \\
0.303 & 0.291 \\
2.192 & 2.178 \\
0.844 & 0.829\end{array}$ \\
\hline & 0.8 & 1.2 & 1.6 & 2.0 & \\
\hline
\end{tabular}
potential and response $\left|\boldsymbol{f}_{q j l}^{+}\right|$; second row, the forcing term on the body surface due to the body motion $\left|\boldsymbol{f}_{B B j l}^{+}\right|$; third from, the forcing term on free surface, incident potential and the scattered potential from fixed body $\mid \boldsymbol{f}_{l j l}^{+}$ $+\boldsymbol{f}_{B I j l}^{+}+\boldsymbol{f}_{F j l}^{+} \mid$; fourth row is the total QTF, $\left|\boldsymbol{f}_{j l}^{+}\right|$and first column, the present calculation ; second column, calculated results by Kim and $\mathrm{Yue}^{10)}$

$$
\begin{aligned}
& -\frac{1}{2} \rho g A w\left[\alpha_{3 j}^{(1)}\left(x_{f} \alpha_{1 l}^{(1) *}+y_{f} \alpha_{2 l}^{(1) *}\right)\right. \\
& \left.+\alpha_{3 l}^{(1) *}\left(x_{f} \alpha_{1 j}^{(1)}+y_{f} \alpha_{2 j}^{(1)}\right)\right] \boldsymbol{k}
\end{aligned}
$$

ただし, $\boldsymbol{N}=\boldsymbol{n} /\left(1-n_{3}^{2}\right)^{1 / 2}, A_{w}$ は水線面積, $x_{f}$ と $y_{f}$ は水線 面の中心座標, $\zeta^{(1)}$ は線形の水面上昇量, $\boldsymbol{f}^{(1)}$ は 1 次の波力 ベクトルである。上記定義から次のような関係を満たす。

$$
\boldsymbol{f}_{j l}^{+}=\boldsymbol{f}_{l j}^{+}, \quad \boldsymbol{f}_{j l}^{-}=\boldsymbol{f}_{l j}^{-*}
$$

\section{4 数值計算結果}

本理論に基づき, 3 次元任意浮体の QTF を計算する数値 計算法を開発した。物体表面及び自由表面の分割要素には アイソパラメトリック要素（8 節点 4 角形及び 6 節点 3 角 形要素）を用いた。本計算法の適用性を調査する為に，も っとも簡単な半径 $a$ の半球浮体（水深 $d=3 a$ ) を用いた。 Table. 1, 2 に和及び差の周波数成分を持つ 2 次波力の QTF の振幅の本法による計算結果と Kim and Yue ${ }^{10)} に$ よるコンスタントパネル法による同じ計算結果の比較を無 次元波数 $k a$ をべースに行列の形で示す。 Kim and Yue は, (19) 式左辺第 2 項を $\phi_{D j l}^{ \pm}$を直接求めることなく, 2 次の

Table 2 Comparison of difference frequency QTFs for

\begin{tabular}{|c|c|c|c|c|c|}
\hline \multirow{2}{*}{$k_{l} a$} & $k_{2} a$ & 1.0 & 1.2 & 1.6 & 2.0 \\
\hline & Pres. Kim & Pres. Kim & Pres. Kim & Pres. Kim & Pres. Kim \\
\hline \multirow{4}{*}{1.0} & $.672 \quad .669$ & $.068 \quad .071$ & $\begin{array}{ll}.526 & .522\end{array}$ & $\begin{array}{ll}.361 & .359\end{array}$ & $\begin{array}{ll}.359 & .358\end{array}$ \\
\hline & $.000 \quad .000$ & $.000 \quad .000$ & $.053 \quad .053$ & .091 091 & $.148 \quad .147$ \\
\hline & $.000 \quad .000$ & $.000 \quad .000$ & $.064 \quad .062$ & $\begin{array}{ll}.162 \quad .158\end{array}$ & $.254 \quad .269$ \\
\hline & $\begin{array}{ll}.672 & .669\end{array}$ & $.068 \quad .071$ & $\begin{array}{lll}.480 & .475\end{array}$ & .286 & .243 .196 \\
\hline \multirow{4}{*}{1.2} & $\begin{array}{ll}.150 & .135\end{array}$ & $.490 \quad .494$ & $\begin{array}{ll}.885 & .878\end{array}$ & $\begin{array}{ll}.723 & .718\end{array}$ & $.658 \quad .653$ \\
\hline & $.061 \quad .081$ & $.000 \quad .000$ & $\begin{array}{ll}.000 & .000\end{array}$ & $\begin{array}{ll}.010 \quad 010\end{array}$ & $.036 \quad .036$ \\
\hline & $.056 \quad .046$ & $.000 \quad .000$ & $.000 \quad .000$ & $.060 \quad .060$ & .171 .160 \\
\hline & $.215 \quad .213$ & $\begin{array}{ll}.490 & .494\end{array}$ & $\begin{array}{ll}.885 & .878\end{array}$ & $.666 \quad .660$ & $.498 \quad .487$ \\
\hline \multirow{4}{*}{1.6} & $\begin{array}{ll}.197 & .204\end{array}$ & $.514 \quad .516$ & $.425 \quad .426$ & .655 $\quad .652$ & $.643 \quad 639$ \\
\hline & $.102 \quad .130$ & $.027 \quad .040$ & $.000 \quad .000$ & $.000 \quad .000$ & $.008 \quad .008$ \\
\hline & $.150 \quad .065$ & $\begin{array}{ll}.042 & .040\end{array}$ & $.000 \quad .000$ & $.000 \quad .000$ & $.040 \quad .042$ \\
\hline & $.407 \quad .369$ & $\begin{array}{ll}.813 & .820\end{array}$ & $.425 \quad .426$ & $\begin{array}{ll}.655 & .652\end{array}$ & $\begin{array}{ll}.585 & .581\end{array}$ \\
\hline \multirow{5}{*}{2.0} & $\begin{array}{ll}.253 & .259\end{array}$ & $.475 \quad .476$ & $.384 \quad .386$ & $\begin{array}{ll}.367 & .370\end{array}$ & .649 \\
\hline & $.148 \quad .177$ & $\begin{array}{ll}.062 & .077\end{array}$ & $.012 \quad .023$ & $.000 \quad .000$ & $.000 \quad .000$ \\
\hline & $\begin{array}{ll}.238 & .171\end{array}$ & 126 & $\begin{array}{ll}.039 & .041\end{array}$ & $.000 \quad .000$ & $.000 \quad .000$ \\
\hline & $\begin{array}{ll}.368 & .383\end{array}$ & $\begin{array}{ll}.789 & .788\end{array}$ & .669 $\quad .676$ & $.367 \quad .370$ & $.649 \quad .646$ \\
\hline & 1.0 & 1.2 & 1.6 & 2.0 & \\
\hline
\end{tabular}
a freely moving hemisphere in a water depth of $h / a=3$. The upper right triangular matrix is for the horizontal force, and the lower the vertical force. Computed values are for : first row, the quadratic term from the first order potential and response $\left|\boldsymbol{f}_{q_{j l}}^{-}\right|$; second row, the forcing term on the body surface due to the body motion $\left|\boldsymbol{f}_{B B j l}^{-}\right|$; third from, the forcing term on free surface $\left|\boldsymbol{f}_{F j l}\right|$; fourth row is the total QTF, $\left|\boldsymbol{f}_{j l}^{-}\right|$and first column, the present calculation; second column, calculated results by $\mathrm{Kim}$ and $\mathrm{Yue}^{10)}$ 
radiation ポテンシャルの自由表面条件と $\partial \psi_{k}^{+} / \partial n=n_{k}$ を 満たす補助ポテンシャル $\psi_{k}^{ \pm}$を使って

$$
\begin{gathered}
\iint_{S_{B}} \phi_{\bar{D} j l}^{ \pm} n_{k} d S=\iint_{S_{B}} \psi_{k}^{ \pm}\left(B_{j l}^{ \pm}-\frac{\partial \phi_{I j l}^{ \pm}}{\partial n}\right) d S \\
+\frac{1}{g} \iint_{S_{F}} Q_{j l}^{ \pm} \psi_{k}^{ \pm} d S \\
\text { と変形し, } 2 \text { 次波力の QTF を次の } 5 \text { 項 } \\
\boldsymbol{f}_{j l}^{ \pm}=\boldsymbol{f}_{I j l}^{ \pm}+\boldsymbol{f}_{B B j l}^{+}+\boldsymbol{f}_{B ! j l}^{ \pm}+\boldsymbol{f}_{F j l}^{ \pm}+\boldsymbol{f}_{q j l}^{ \pm}
\end{gathered}
$$

の和として表し, 各成分力を評価している。本法では, 直 接 $\boldsymbol{f}_{j l}^{ \pm}$が求められるのでこのような分離は必要ないが, 比 較の為に上式に相当する各成分力を求めた。

表の右上半尔は, サージ力の QTF, 左下半分はヒーブ力 の QTF を表している。Table 1 は, 和の周波数成分力の QTF の振幅を表し，(24)式に基づき各行列要素の第 1 行 は, 1 次ポテンシャルと応答による成分力 $\left|\boldsymbol{f}_{q j l}^{+}\right|$, 第 2 行は浮 体表面の強制速度項による成分力 $\left|\boldsymbol{f}_{B B j l}^{+}\right|$, 第 3 行は, 入射波 及び自由表面の強制压力項による成分力 $\left|\boldsymbol{f}_{l j l}^{+}+\boldsymbol{f}_{B l j l}^{+}+\boldsymbol{f}_{F j l}^{+}\right|$, 第 4 行はトータル QTF $\left|\boldsymbol{f}_{j l}^{+}\right|$である。各成分力は $\rho g a A_{j} A_{l}$ で割って無次元化している。一方 Table 2 は, 差の周波数 成分力の QTF の振幅を表し, 各行列要素の第 1 行は 1 次 ポテンシャルと応答による成分力 $\left|\boldsymbol{f}_{q j l}^{-}\right|$, 第 2 行は浮体表面 の強制速度項による成分力 $\left|\boldsymbol{f}_{B B j l}^{-}\right|$, 第 3 行は自由表面の強 制圧力項による成分力 $\left|\boldsymbol{f}_{F j l}^{-}\right|$, 第4行はトータルのQTF $\left|\boldsymbol{f}_{j l}^{-}\right|$ を表す。各成分力は $\rho g a A_{j} A_{l}^{*}$ で割って無次元化している。 表の各行列要素の第 1 列は本法による計算結果, 第 2 列は Kim and Yue の計算結果である。本法に基づく計算で使用 した物体表面の要素数は 400, 自由表面は 200 である。自由 表面積分の第 1 領域 $S_{F_{1}}$ は, 半径の 5.7 倍に取った。この表 から，ヒーブ力の QTF の $\left(k_{1} a, k_{2} a\right)=(1.6,1.2)$ の点を除 き両者は, 非常に良く一致しており，本法による計算結果 は, 2 次のポテンシャル理論の範囲内において十分信頼で きる結果であると思われる。

\section{3. 実 験}

\section{1 模型概要}

実験に使用したTLP 模型は, Fig. 6 に示すような Snorre TLPの縮小模型（総アルミ製）で，その主要目は， Table 3 に示す通りである。

\section{2 波力計測実験}

波力計測実験は，本模型を 3 分力計 (日章製, $50 \mathrm{kgf} / 20$ $\mathrm{kgfm}$ 容量, 分解能 $50 \mathrm{gf} / 20 \mathrm{gfm}$ ) を介して当所の海洋構造 物試験水槽 (長さ $40 \mathrm{~m}$, 幅 $30 \mathrm{~m}$, 水深 $1.8 \mathrm{~m}$ ) の台車に固 定し, サージ力, ヒーブ力及びピッチモーメントを計測し た。波面上昇は模型の中心から $7.5 \mathrm{~m}$ 横の位置に設置され たサーボ式波高計 (電子工業製, 定格出力 $\pm 8.5 \mathrm{~cm}$, 直線 性限界 $\pm 0.0085 \mathrm{~cm}$ ）による入射波と Fig. 7 に示す位置に おける波高分布を 5 台の容量式波高計（電子工業製，定格 出力 $\pm 30 \mathrm{~cm}$, 直線性限界 $\pm 0.003 \mathrm{~cm}$ )によって計測した。
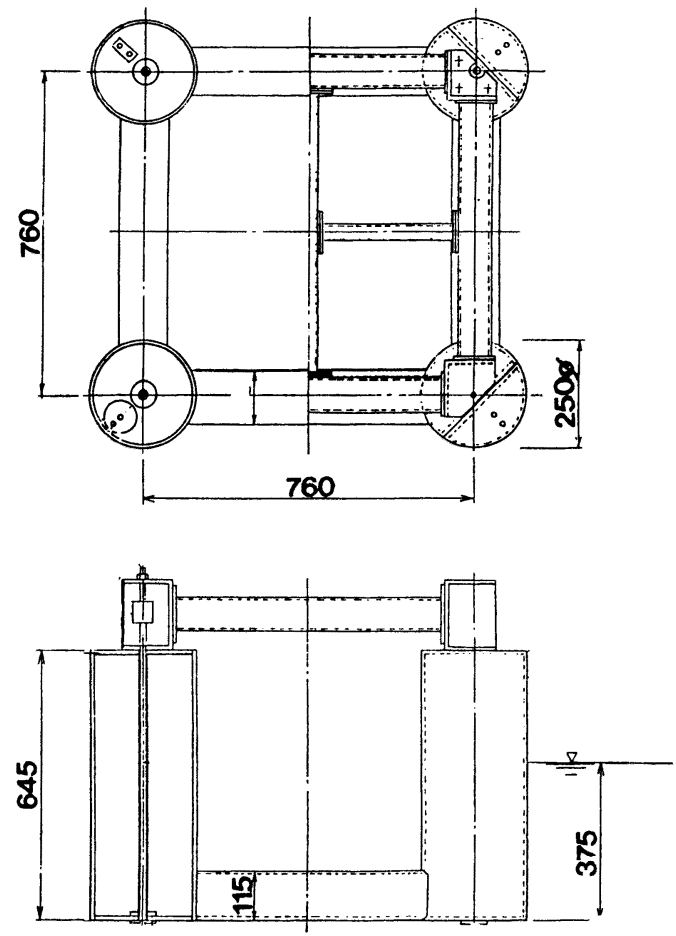

(unitmm)

Fig. 6 Configuration of TLP hull model

Table 3 Principal particular of TLP model

\begin{tabular}{|c|c|c|}
\hline Items & Unit & \\
\hline Column diameter & $\mathrm{cm}$ & 25.0 \\
\hline Pontoon height & $\mathrm{cm}$ & 11.5 \\
\hline Pontoon breadth & $\mathrm{cm}$ & 11.5 \\
\hline Platform Draft & $\mathrm{cm}$ & 37.5 \\
\hline Centre dist. betw. column/long dir. & $\mathrm{cm}$ & 76.0 \\
\hline Centre dist. betw. column/trans dir. & $\mathrm{cm}$ & 76.0 \\
\hline Platform displacement & $\mathrm{kg}$ & 103,125 \\
\hline Freeboard & $\mathrm{cm}$ & 27.0 \\
\hline Water depth & $\mathrm{cm}$ & 310 \\
\hline
\end{tabular}

使用した波は，規則波と不規則波であり，規則波の周波数 は, $0.4 \mathrm{~Hz}$ から $2.0 \mathrm{~Hz}$ の範囲, また波高は, $3.0 \mathrm{~cm}$ から $6.0 \mathrm{~cm}$ の範囲で変化させた。不規則波発生にはランダムノ イズ発生器 ( $\mathrm{NF}$ 製) とバンドパスフィルター ( $\mathrm{NF}$ 製, 減 衰率 $24 \mathrm{~dB} /$ oct）を用い, 中心周波数 $0.8 \mathrm{~Hz}$ から $1.2 \mathrm{~Hz}$ の範囲に変化させた。 


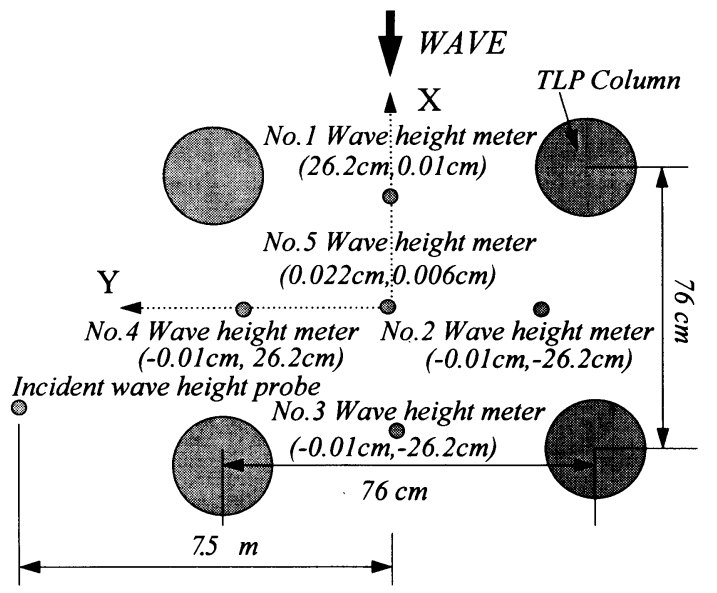

Fig. 7 Position of wave height meters and coordinate system

\section{4. 結果及び考察}

\section{1 線形波力}

Fig. 8 にサージ，ヒーブ及びピッチの 1 次 (線形) 波力特 性を示す。図中の記号は，規則波中模型実験結果を表し， 実線は本法に基づく線形理論計算結果である。実験結果は,
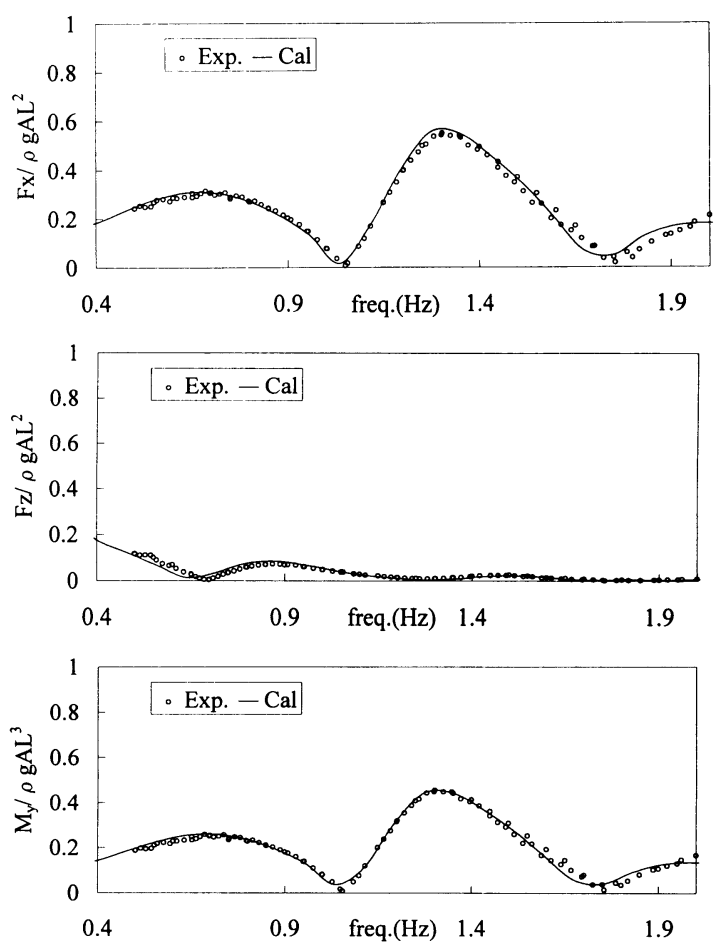

Fig. 8 First order surge and heave forces on TLP
高速フーリエ変換手法を用いて波周波数と同じ成分を抽出 している。この図から判るように, 両者は非常に良く一致 している。Fig. 9 は TLP 内部の線形波高分布を示す。上の 図は実測結果であり,下の図は理論計算結果である。両者 の相関は非常に良い。従って, 線形範囲においては, 計算 結果と実験結果は非常に良く一致しており, 線形ポテンシ ヤル理論の妥当性が検証された。

\subsection{2 次の波力の倍周波数成分力}

Fig. 10 から 12 は，2 次の波力の倍周波数成分力の特性 を波周波数を横軸にとり示したものである。Fig. 10 がサー ジ力, Fig. 11 がヒーブ力, Fig. 12 がピッチモーメントであ る。図中の○印は規則波中実験結果であり, 記号は不規則 波中の実験結果である。図中の $f_{p}$ の值はスペクトル中心周 波数である。実線は, 計算結果を表し, 計算には, 本法に 基づく高次面境界要素法を用い, 浮体表面, 自由表面をそ れぞれ 992,608の 2 次アイソパラメトリック要素に分割し た。自由表面積分に関し $S_{F_{1}}$ と $S_{F_{2}}$ の境界である円筒境界 半径 $R_{J}$ は TLP のコラム間の距離の 2 倍をとり, $S_{F_{2}}$ と $S_{F_{3}}$ 間距離は水深の 2 倍にとった。不規則波中での実験結 果は, クロスバイスペクトル解析 (例えば, Dalzell ${ }^{11}$ ) 参照 の事) から求めた。

これらの図から，ヒーブ方向の 2 次の波力の和の周波数 成分力は実験結果と計算結果は非常に良く一致しているこ とが判る。一方, サージ及びピッチモーメントに関しては, 波周波数 $1.4 \mathrm{~Hz}(k L=6, k$ は波数， $L$ はコラム間隔）ま では実験結果と計算結果は良く一致するもののそれ以上の 周波数範囲で両者は大きく異なっている。なお, Fig. 13 は, スプリンギング強制力（ヒーブ力の 2 次波力の和の周波数 成分力)の QTF の計算結果を示す。スプリンギング強制力 のQTF は対角成分（倍周波数成分）に密度が集中してい る。

\section{3 高次の波力と TLP 内の波浪場との関係}

Fig. 14 は, 実験から求めたピッチモーメントの 3 次オー ダーの成分力を示している。この図の $\times$ 印は 1 次成分力の 実験結果である。波周波数 $1.3 \mathrm{~Hz}$ 付近でかなり大きな 3 次の成分力が起こり, $1 \mathrm{~Hz}$ 以上でのその周波数特性は, 1 次成分力の特性とほとんど同じになることが判る。この原 因は不明であるが，1 次波力の高次成分へのもれが生じて いるものと考えられる。こうした高次ピッチモーメントが どのような波浪場で生じるかを調べることにする。Fig. 15 は, 波周波数 $1.35 \mathrm{~Hz}$, 波高 $5.4 \mathrm{~cm}$ の規則波中での, TLP 内部の波高の変化と波力の変化を時系列ベースで示したも のである。この図から以下のことが判る。入射波に比べて TLP 内の空間波形がかなり急峻になり, No. 1 波高計の位 置 (浮体前部)において，平坦な谷でかつNo. 3 波高計の位 置（浮体後部）で急峻な山となるとき，変曲点を有する頭 下げの非線形ピッチングモーメントが生じる（非線形サー ジ力も生じる)。この力は, 浮体内部で生じる steep 波の 

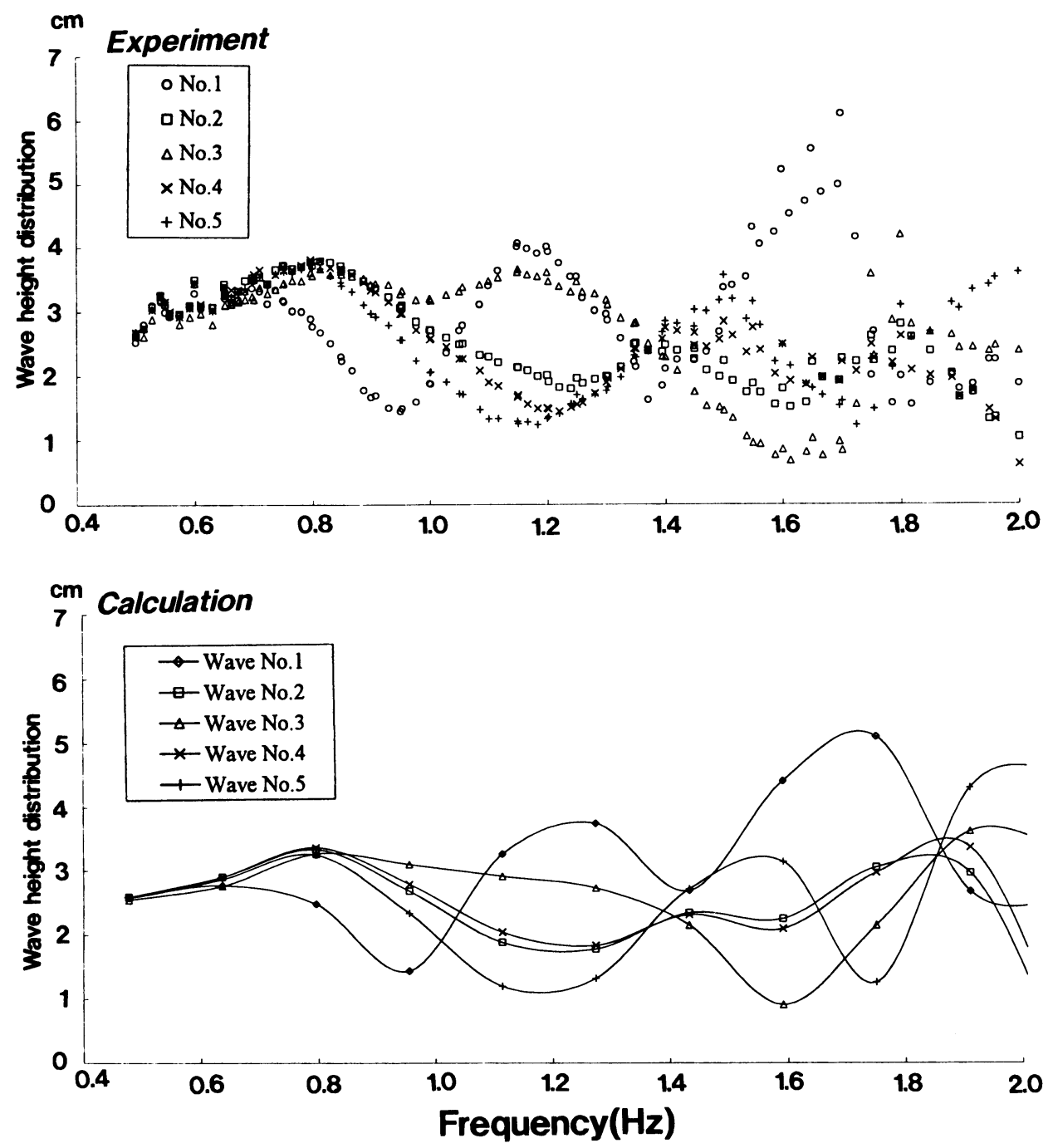

Fig. 9 Wave height distribution inside TLP (upper figure : experiment, lower figure : calculation)

steep front と steep back で起こっている。

次に不規則波中でも同じょうな現象が生じるか調査す る。Fig. 16 にスペクトル中心周波数 $0.8 \mathrm{~Hz}$ での入射波と TLP 内の水面上昇量の時系列を示す。Fig. 17 はその時の サージ力, ヒーブ力, ピッチングモーメント及び $2 \mathrm{~Hz}$ 以上 の高周波数成分のサージ力の時系列を表す。両図から次の ことが判る。

steep な高波が浮体に入射すると, 浮体前部で波はより steep な波に変形し，波峰分裂 (crest pairing) によると思 われる高周波数の新たな波が生じる。この高周波数の波が 生じた瞬間にサージ力に有意な高周波数成分力が生じる (ピッチモーメントにも生じる)。不規則波中での現象と規 則波中の現象は少し異なるようであるが, いずれにせよこ
うした現象の発生は, 浮体と波との流体力学的非線形相互 作用により波がより steep な非線形波になることに起因し ているものと思われる。

Fig. 17 の破線は, 次式による 2 次の波力までのシミュレ ーション計算結果を示している。

$$
\begin{aligned}
F_{k}^{(2)}= & \int_{-\infty}^{\infty} g_{k}^{(1)}(\tau) \zeta(t-\tau) d \tau \\
& +\iint_{-\infty}^{\infty} g_{k}^{(2)}\left(\tau_{1}, \tau_{2}\right) \zeta\left(t-\tau_{1}\right) \zeta\left(t-\tau_{2}\right) d \tau_{1} d \tau_{2}
\end{aligned}
$$

ただし $\zeta(t)$ は線形波と仮定される入射波の時系列であ る。 $g_{k}^{(1)}, g_{k}^{(2)}$ は運動モード $k$ の線形及び 2 次波力のインパ ルス応答関数であり,これは線形及び 2 次の波力の周波数 伝達関数のフーリエ変換から求められる。線形インパルス 


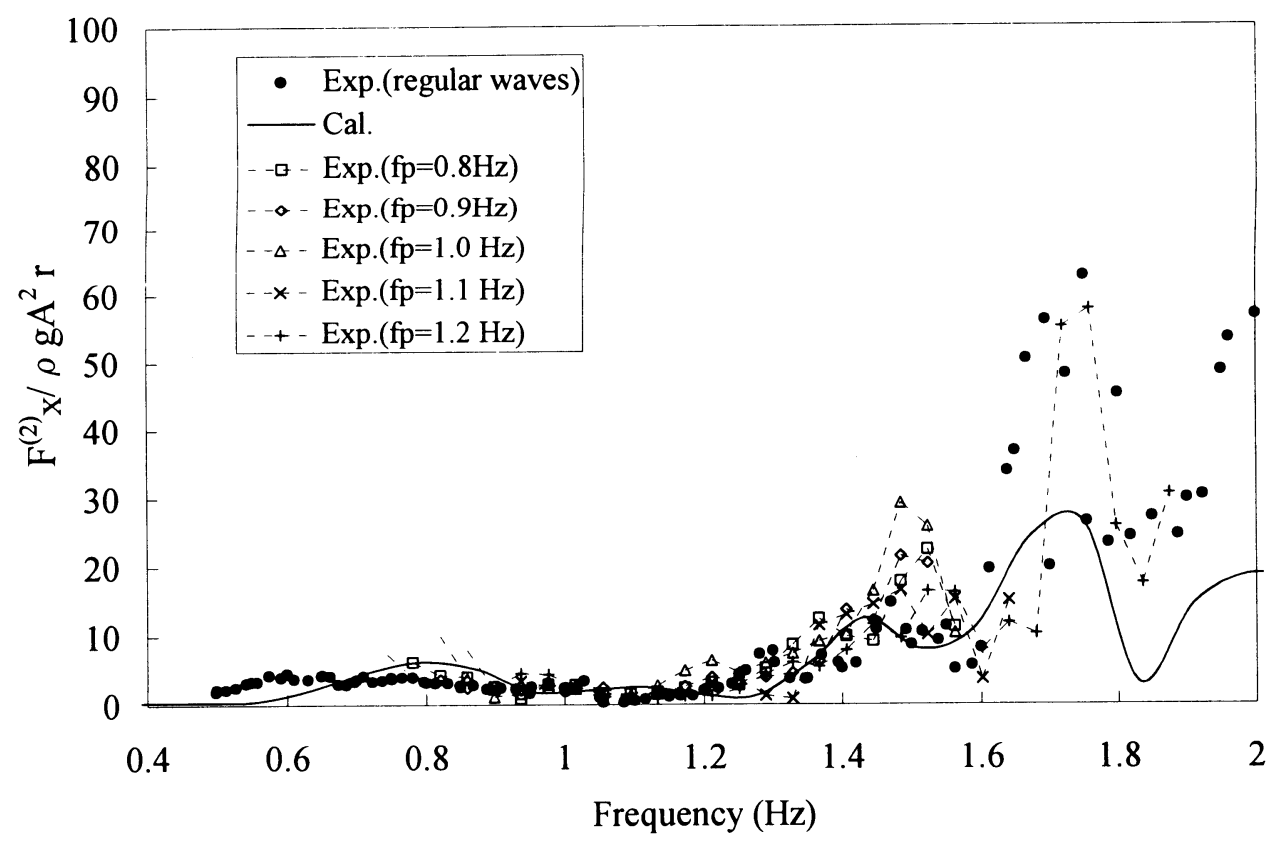

Fig. 10 Second order sum frequency force in surge on TLP

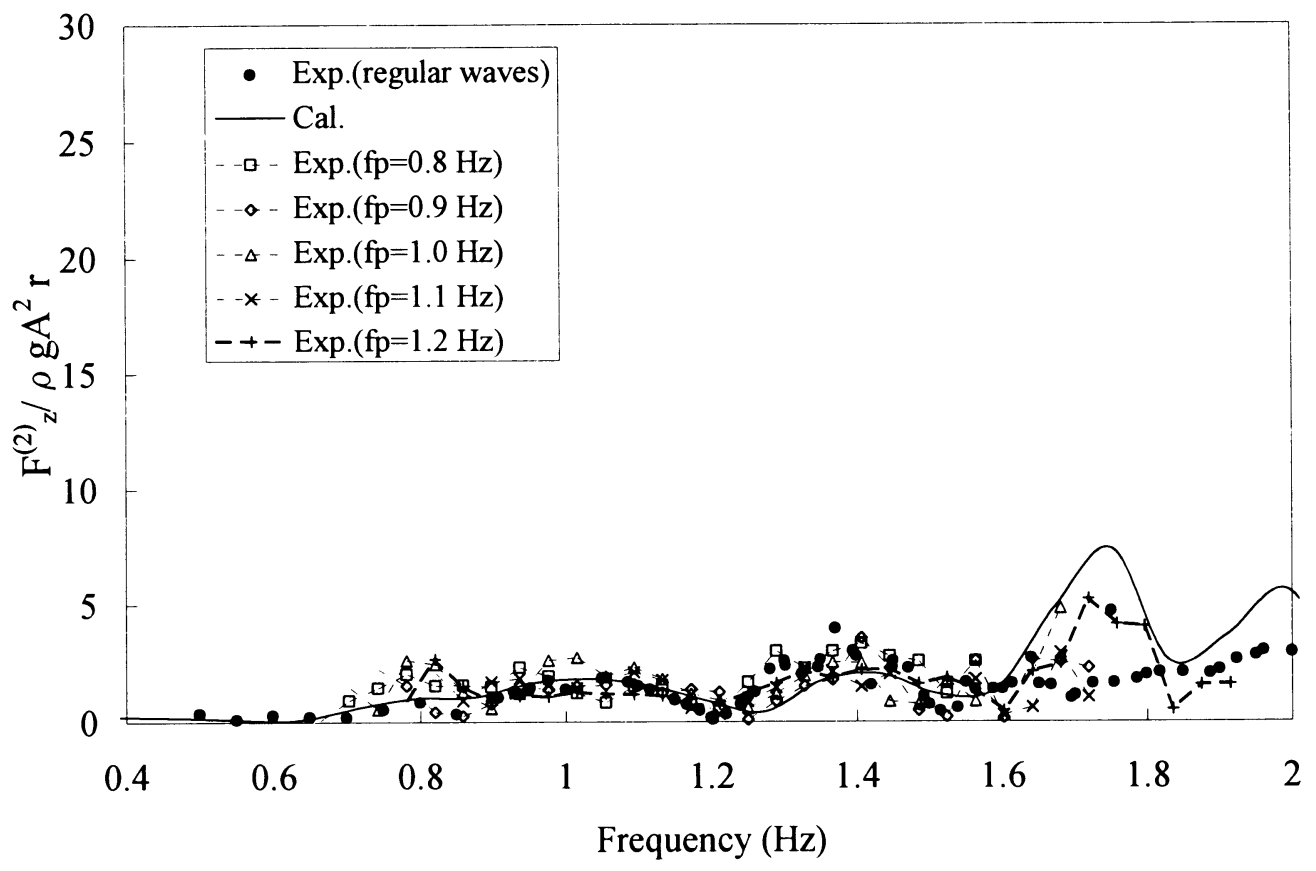

Fig. 11 Second order sum frequency force in heave on TLP 


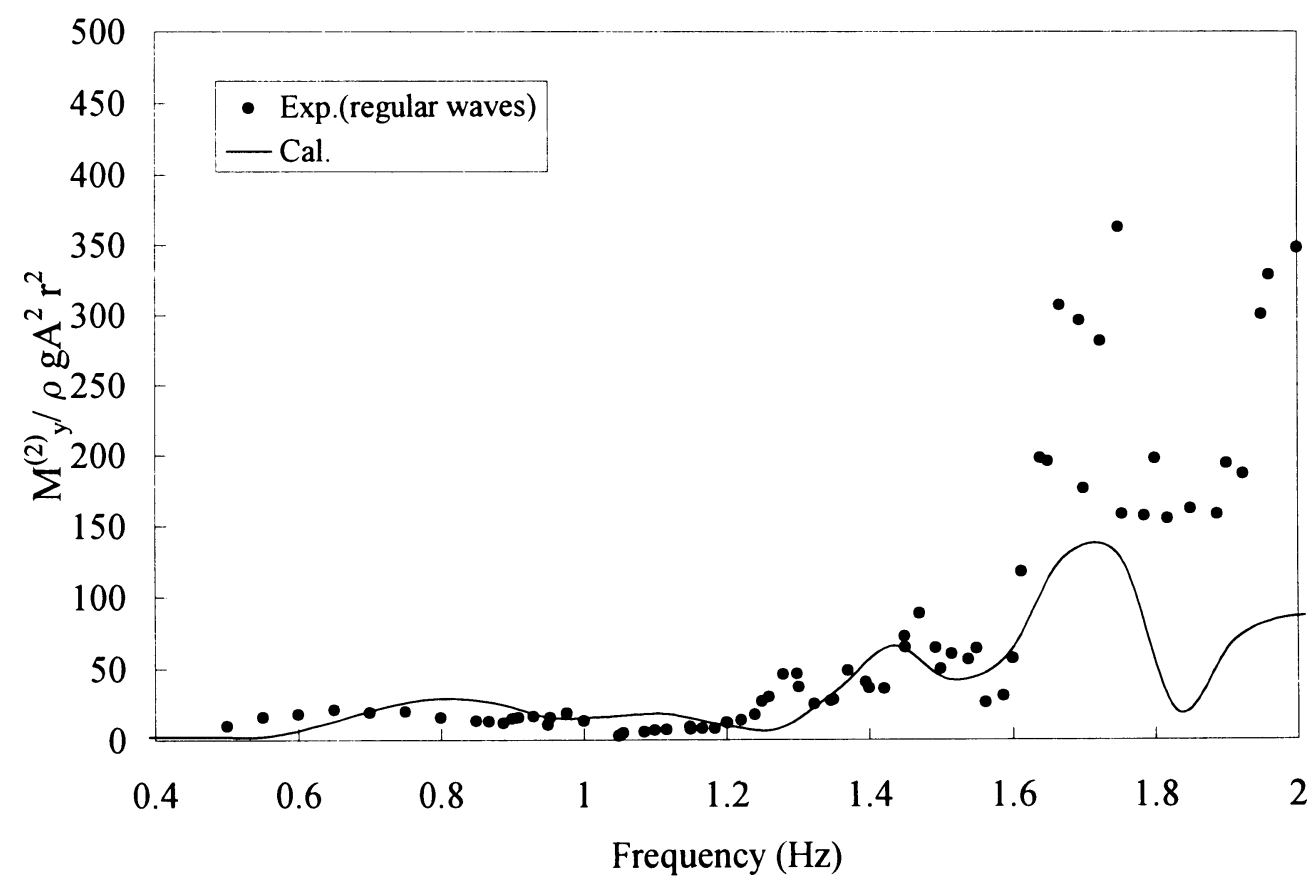

Fig. 12 Second order sum frequency moment in pitch on TLP

\section{Bird eye view}
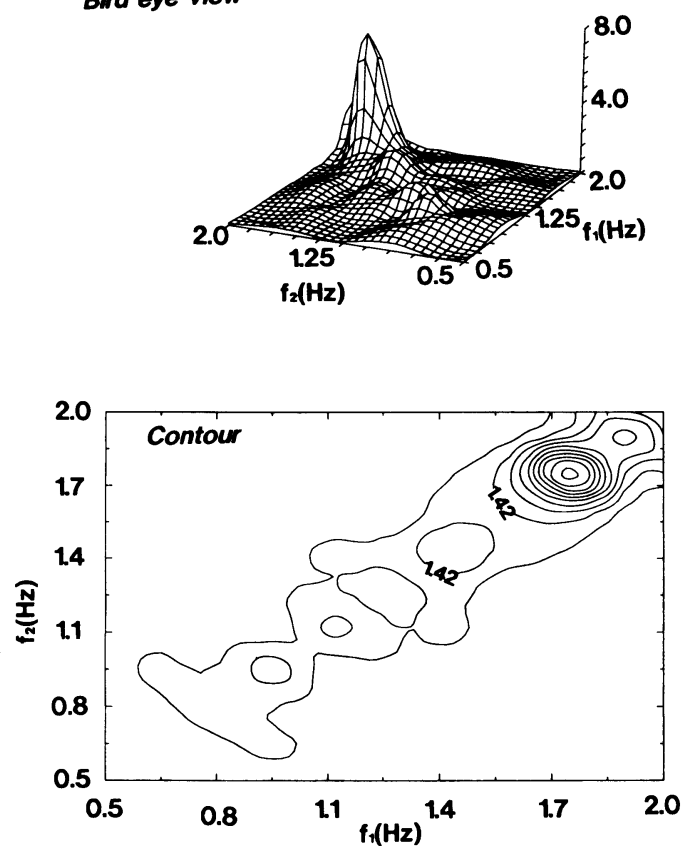

Fig. 13 A calculated result of second order sum frequency force QTF in heave on TLP
応答関数は, $0 \leq \omega<19(\mathrm{rad} / \mathrm{sec})$ の周波数範囲, 2 次のイン パルス応答関数は, $0 \leq \omega_{1}, \omega_{2}<15(\mathrm{rad} / \mathrm{sec})$ の周波数範囲

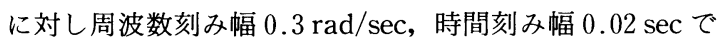
評価した。この図から 2 次までのポテンシャル理論に基づ くシミュレーション計算では実験で得られるような高周波 数成分力は生じないことが判る。なお，時系列に関する実 験結果と計算結果の比較では, QTF の比較と同様にヒーブ 力に関しては両者はほほ良く一致しているが, サージ及び ピッチモーメントに関しては実験結果の方が計算結果より も大きい。

\section{5. 結 論}

本論で得られた主要な成果は次の通りである。

1） 2 次波力の応答関数を精度良く計算する手法を新た に開発した。この方法は, Kim や松井らの手法に比 ベ, 直接 2 次のポテンシャルを求めている点が異な る。

2） 4 コラム・4 ポンツーン TLP に働く線形波力及び浮 体周りの線形波浪場は線形ポテンシャル理論で説明 できる。

3）サージ及びピッチの 2 次波力の和周波数成分力に関 しては, 波周波数 $1.4 \mathrm{~Hz}(k L=6, k$ は波数, $L$ は TLP のコラム間の距離) までは 2 次のポテンシャル理論に 


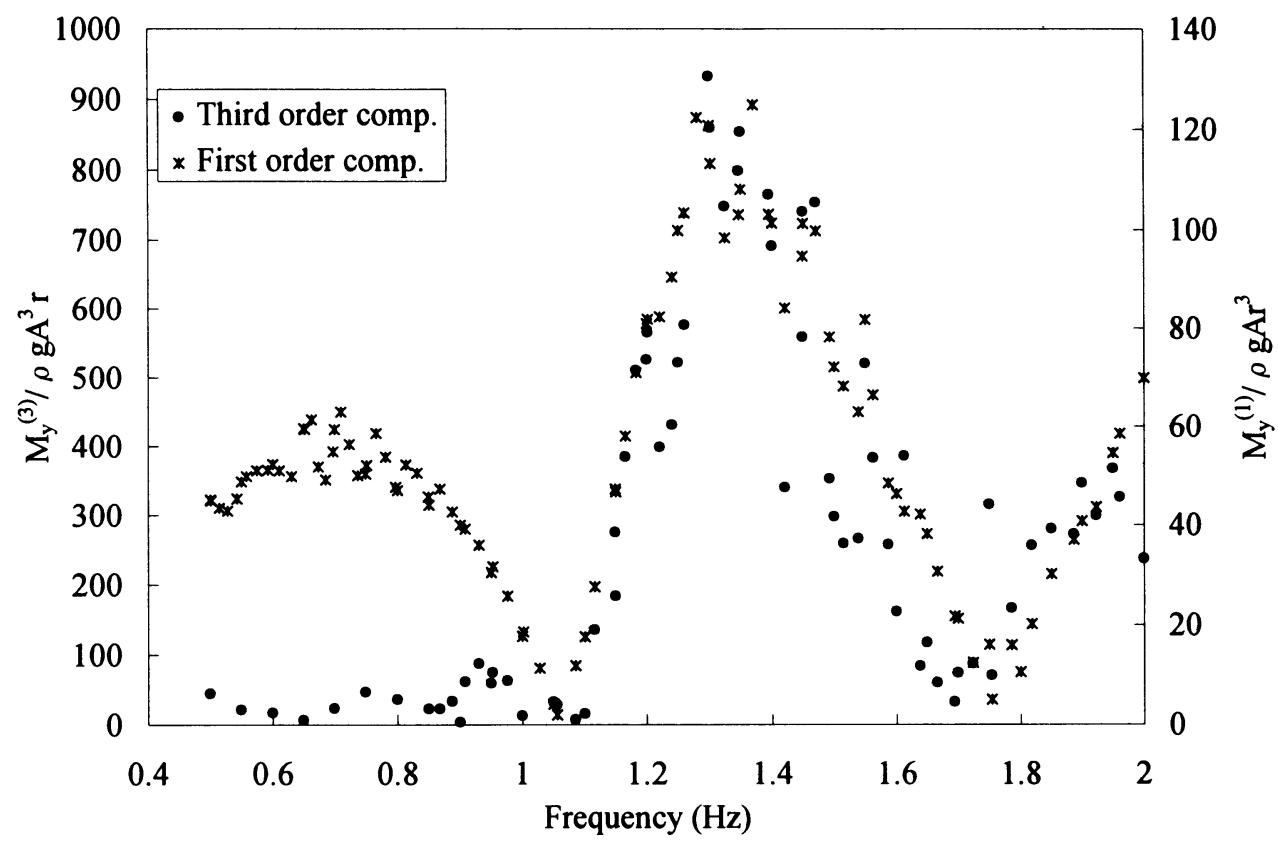

Fig. 14 Comparison between first and third order pitch moments

Wave freq $: 135 \mathrm{~Hz}$ Wave height: $5.4 \mathrm{~cm}$

Incident wave

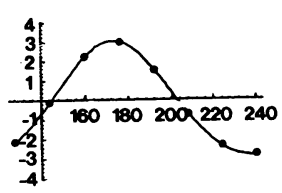

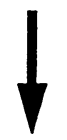
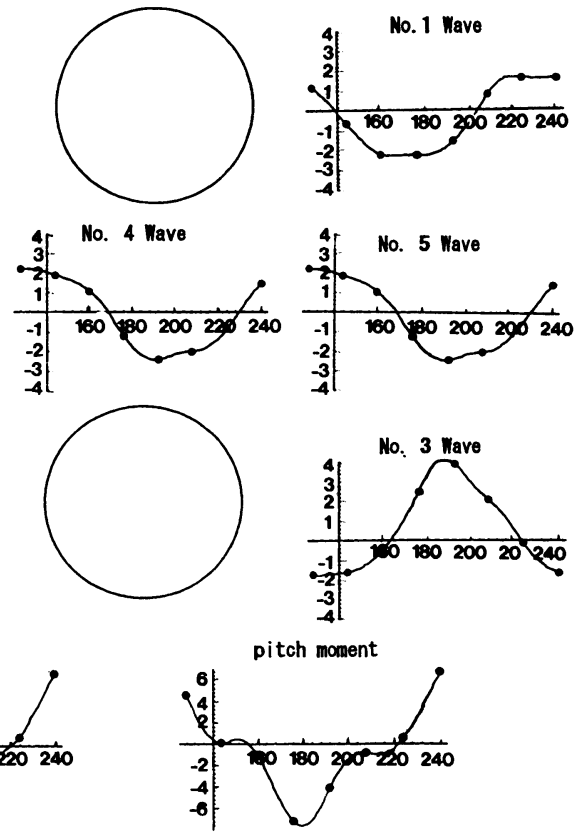

Wave

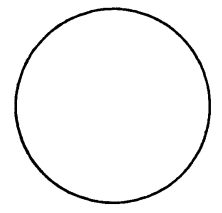

No. 2 Nave
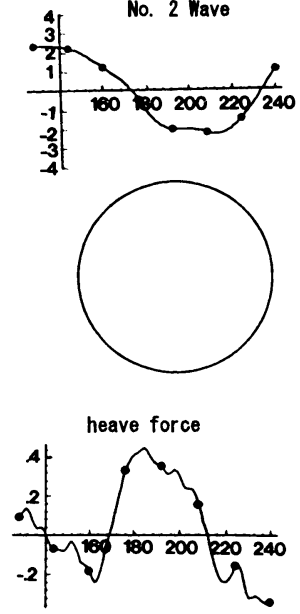

Fig. 15 Relation among wave forces and wave field 

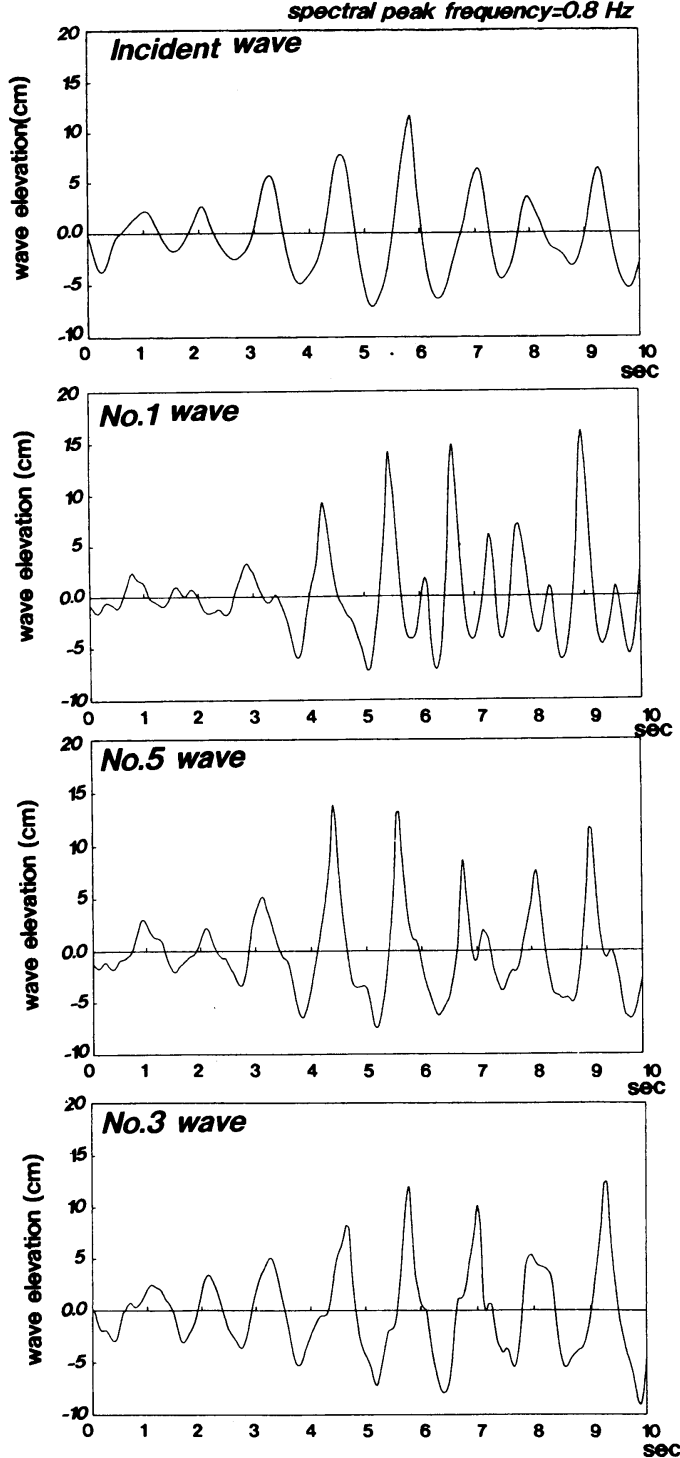

Fig. 16 An example of time histories of incident wave and surface elevation distribution inside TLP

よる計算結果と良く一致するが, それ以上の周波数で は一致しない。ヒーブに関しては, 波周波数 $1.6 \mathrm{~Hz}$ $(k L=7.84)$ まで両者は良く一致する。

4）波基本周波数の 3 倍の周波数成分をもつ有意なピッ チモーメントが波周波数 $1.2 \mathrm{~Hz}(k L=4.4)$ 以上で生 じ, その振幅の周波数特性は振幅值そのものは異なる が, 1 次のピッチモーメントの周波数振幅特性と同じ 特性を有している。また,この 3 次オーダーの力は, TLP 内で入射波が steep 波に変形し, その波の steep front と steep back で起こる。
Surge force
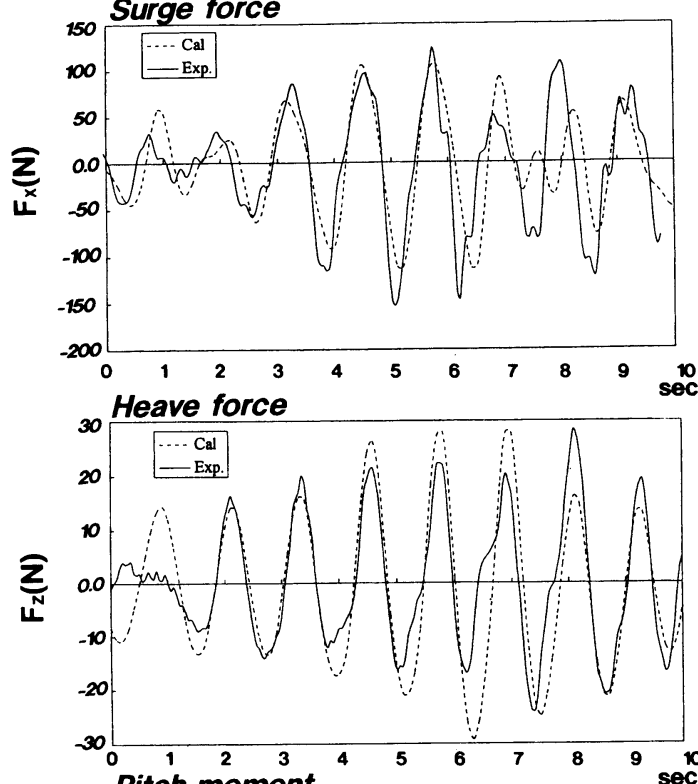

Pitch moment
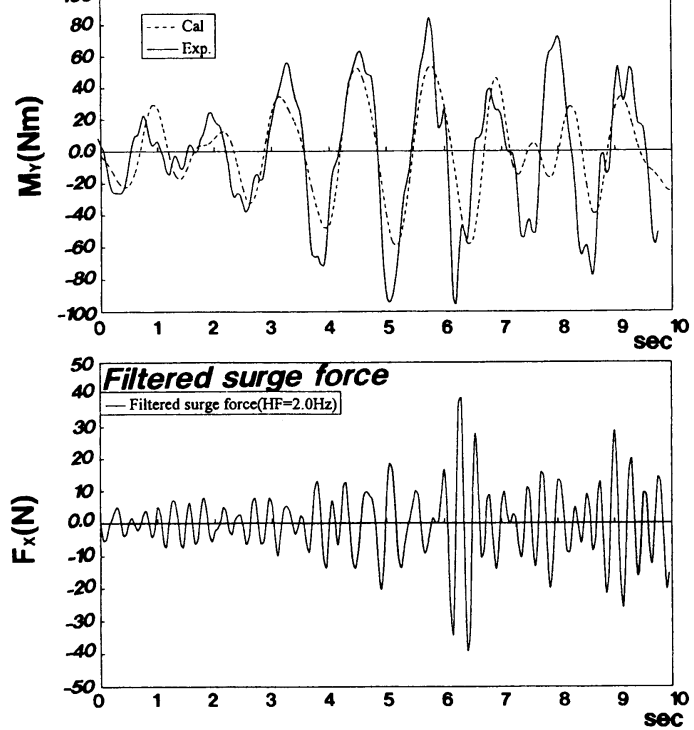

Fig. 17 An example of time histories of surge force, heave force, pitch moment and filtered surge force. The solid line is the experimental result and the broken line shows the calculation result including second order force.

5）不規則波中においても 2 次のオーダー以上の高次の 波力が生じる。この力は, TLP 内で生じる steep 波の 波峰分裂によるものと思われる高周波数の波によっ て生じる。

今後は, 高周波数域における 2 次波力の実験と計算結果の difference の解明と三次オーダーの波力及び構造物周りの 
wave kinematics とリンギング応答との相関を調査する 予定である。

終わりに, 本研究は科学技術庁重点基礎研究費による「不 規則波浪場と浮体間の非線形相互作用に関する基礎的研 究」の一貫として実施したものである。本研究の実施に当 たり関係各位に御礼申し上げます。

\section{参 考 文 献}

1）吉田宏一郎, 米家卓也, 岡徳昭：緊張係留プラット フォームの動的応答特性, 日本造船学会論文集, 第 146 号, pp. 195-205, 1979.

2) Petrauskas, C. and Liu, S. V.: Springing Force Response of a Tension Leg Platform, Proc. 19th Offshore Technology Conference, OTC 5458, Houston, Texas, Vol. 2, pp. 333-341, 1987.

3) De Boom, W. C., Pinkster, J. A., and Tan, P. S. G. : Motion anf Tether Force Prediction for a TLP. J. Waterways, Port, Coastal and Ocean Eng., Proc. ASCE, Vol.110, No.4, pp. 472-486, 1984.

4）松井徹哉, 酒向裕司：緊張係留浮体の 2 次波強制力 による応答と係留力，日本造船学会論文集，第 169 号, pp。151-164, 1990.

5）松井徹哉, 酒向裕司, 野津剛：テンションレグプラ ットフォームの非線形周波数和応答, 日本建築学会
構造系論文報告集, 第 449 号, pp. 195-206, 1993.

6) Kim, M. H. : Second - Order Sum - Frequency Wave Load on Large-Volume Structures, Applied Ocean Research, Vol.13, No.6, pp. 287296, 1991.

7) Natvig, B. J. : A Proposed Ringing Analysis Model for Higher Order Thether Response, Proc. of the Fourth ISOPE Symp., Vol.1, pp. 40-51, 1994.

8) Teng, B. and Eatock Taylor, R. : A BEM Method for Second-order Wave Action on a Floating Body in Monochromatic Waves, Int. Conf. on Hydrodynamics, Wuxi, 1994, pp. 274-281.

9) Teng, B. and Eatock Taylor, R.: New Higher Order Boundary Element Methods for Wave Diffraction/Radiation, Applied Ocean Research (to be published), 1995.

10) Kim, M. H. and Yue, D. K. P.: The Complete Second-order Diffraction Solution for a an Axisymmmetric Body, Part II, Bichromatic Incident Waves and Body Motions, Journal of Fluid Mechanics, Vol. 211, 1990.

11) Dalzell, J. F. : Cross-Bi-Spectral Analysis, Application to Ship Resistance in Waves, Jour. Ship Research, Vol. 18, 1974. 